\title{
The Reflections of Supply Chain Management Practices on R\&D
}

\author{
Mert KILIÇ1 \\ Harun DEMIRKAYA ${ }^{2}$ \\ Faculty of Business, Department of Management \& Organization, Kocaeli University
}

\begin{abstract}
The globalization of the world brings lots of interferences and relationships for the firms to have competitive advantage. As the logistics services has a very important role for both reducing the direct costs and the customer satisfaction, Supply Chain Management increases its importance by the large area of its effect for both inbound and outbound processes of logistics. R\&D is also very critical for the firms to sustain themselves in the age of competition. The customers always desires the best and the most brand-new products on the cheapest price. So examining the relationship between these two very important factors is inevitable. In this paper, it is examined that what is the reflections of supply chain management practices on R\&D.
\end{abstract}

Keywords: Logistics, Supply Chain Management, R\&D, Competitive Advantage.

\section{Introduction}

Nowadays, the inner advantages created on the level of production are determined by the integration of not only the firms, but also the third parties just as the customers and the suppliers. Developing technology and increasing needs of the customers bring the necessity for the firms to change their ways of productions from "pushing type production" to "pulling type production". Because of that reasons, firms have to design their production systems and their relationships with the suppliers flexibly, compensating the requirements of the customers. In this way, firms have to increase customer satisfaction as keeping their level of costs and relationships on the optimum level.

The production organizations' opportunity to sustain competitive advantage in the global competition environment depends on:

Production of the different products,

Reducing the costs when sustaining the quality,

Increasing productivity,

Production of the salable products according to the rates of sales.

Restoration of the levels of quality,

Prompt responses to the potential changes of demands (Dursun, 2001; 28)

$R \& D$ is the systematic and creative works for new products and processes of productions. $R \& D$ is the organized endeavors directed to innovation of product and process and increasing scientific information. It's providing development for science and technology.

The humanity has come to the today's level of civilization with systematical works since recent history, but sometimes coincidences had played a big role before the recent history just like the apple, which drops down to head of Newton. Today, national economies and even the businesses came to the level that none of the developments based on coincidences. Therefore, countries and businesses should give the importance to the functions of research and development according to their extent of financial opportunities. For this reasons, Firms try to do their activities of R\&D with a supply chain, completing each other.

In this study, we aim to reveal the extent of the relationship between R\&D and Supply Chain and examine the management, costs and shapes of supply chain. We try to assess how a supply chain could be effective on competitiveness evaluating the cost structure, product and service manufacturing and trade cycle. And also in the process of R\&D product development, as an alternative to the production, we aim to understand what are the reflections of supply chain management practices

\footnotetext{
${ }^{1}$ Corresponding author, , Ph.D Candidate at Kocaeli University

2 Professor Dr. at Kocaeli Univesity,
} 
on R\&D. The remaining of this paper is organized as follows. In Section II the concept of R\&D in general and Supply Chain Management (SCM) in particular are discussed based on a deep literature review. Finally the conclusion part reveals the theoretical and managerial implications of the paper.

\section{Theoretical Background}

\subsection{The Supply Chain: Definition and the Mechanism}

In the activities of the Firms, the procurement activities are procurement of material inputs, procurement of finance, procurement of personnel and procurement of service. Procurement is supplying necessary equipment and possibilities to reach the goal (Tosun, 1971; 404).

By the developments of recent decades, procurement becomes important part of the production process because the inputs of the production are not being produced, they are being purchased now and also the classical way of stocking mentality is changing its way to the logistics \& supply structuring.

These developments caused the creation of the supply chain (Seraslan, 2002; 17). The supply chain management term entered the public domain when Keith Oliver, a consultant at Booz Allen Hamilton, used it in an interview for the Financial Times in 1982. The term was slow to take hold. It gained currency in the mid-1990s, when a flurry of articles and books came out on the subject. In the late 1990s it rose to prominence as a management buzzword, and operations managers began to use it in their titles with increasing regularity (Jacoby, 2009)(Feller, Shunk \& Callarman, 2006) (Blanchard, 2010). Supply Chain Management's commonly accepted definitions are listed as:

The systematic, strategic coordination of traditional business functions and tactics across all business functions within a particular company and across businesses within the supply chain, for the purposes of improving the long-term performance of the individual companies and the supply chain as a whole (Mentzer, 2001)

The management of upstream and downstream value-added flows of materials, final goods, and related information among suppliers, company, resellers, and final consumers.

A customer-focused definition is given by Hines (2004: 76): "Supply chain strategies require a total systems view of the links in the chain that work together efficiently to create customer satisfaction at the end point of delivery to the consumer. As a consequence, costs must be lowered throughout the chain by driving out unnecessary expenses, movements, and handling. The main focus is turned to efficiency and added value, or the end-user's perception of value. Efficiency must be increased, and bottlenecks removed. The measurement of performance focuses on total system efficiency and the equitable monetary reward distribution to those within the supply chain. The supply chain system must be responsive to customer requirements."(Hines, 2004).

The integration of key business processes across the supply chain for the purpose of creating value for customers and stakeholders (Lambert, 2008).

Supply chain management encompasses the planning and management of all activities involved in sourcing, procurement, conversion, and logistics management according to the Council of Supply Chain Management Professionals (CSCMP). It also includes coordination and collaboration with channel partners, which may be suppliers, intermediaries, third-party service providers, or customers. Supply chain management integrates supply and demand management within and across companies (Wikipedia).

\subsection{The R\&D: Definition and the Mechanism}

The unit of R\&D refers to investigate activities a firm conducts to improve existing products or to lead to development of new products and procedures (Investopedia). It is defined also as a basic research, instead of having commercial concerns, bringing an objective principle to science and technology and extending the limits of science (Şimşek \& Akın, 2003: 146). In the basic research, the purpose of the researcher is obtaining more information about the subject of the research, not the commercial or practical results to benefit (Devrez, 1970: 238). 
New product design and development is more often than not a crucial factor in the survival of a company. In an industry that is changing fast, firms must continually revise their design and range of products. This is necessary due to continuous technology change and development as well as other competitors and the changing preference of customers. Without an R\&D program, a firm must rely on strategic alliances, acquisitions, and networks to tap into the innovations of others (Wikipedia).

The quick changes on the technology, the demands of customers, the intensity of the competition reduces the lifetime of the products. Firms are making strategic plans of one, five and more years according to these data. In the preparation process of R\&D plans, it should be suitable with the general plans of the firm. Top managers of the firm should design the R\&D programs according to meet the optimum requirements of the business, determine the fields of research and responsibilities of the R\&D unit. Top managers should examine the following list (Barutçugil, 1988:50):

Significant sub-objectives should be developed to direct the research.

It should be made all of the personnel understand the long-term technological requirements of the firm.

The harmony between R\&D works and general business strategy should be provided.

Providing the balance of the program, project choosing and sorting should be compatible with the capacity and the goals of the firm.

To transfer the R\&D findings to the production, R\&D and production plan should be organized.

General management plan, which formed by top management, is the first step of R\&D works. Deciding to research (or not) has the risk and uncertainty. That risks and uncertainties caused by the market from one side and the technology from the other side. But approaching the R\&D attempts only in the terms of risk can be misleading. When deciding, The Decision Tree Diagram makes it easier on the Figure 1.

\section{Figure 1. The Decision Tree Diagram}

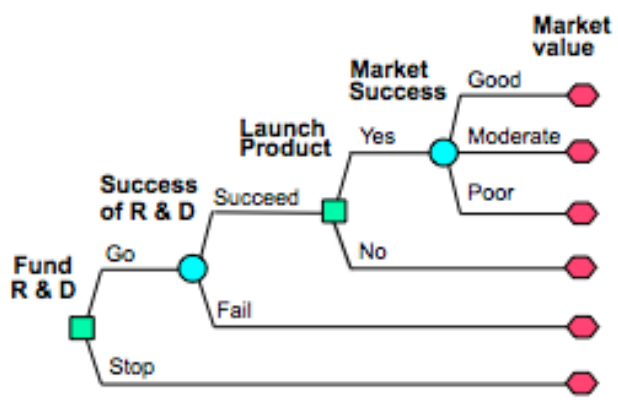

\section{The Reflections of Supply Chain Management Practices on R\&D \\ 3.1. Effects that Adjust Competition on Business.}

Michael E. Porter developed a method, which is known as the five factors, for the managers to analyze the opportunities and threats. Main purpose of the competition strategy should be orientating to the rules of competition and changing this rules in favor of the firm.

There are five-power factor, which determines the competition between the firms (Güleş \& Bülbül, 2004: 47):

Threat of new entrants,

Rivalry among existing competitors,

Bargaining power of buyers,

Bargaining power of suppliers, 
Threat of the substitute products or services.

The total power of these five factors determines the income, which firms will gain from the investments above their capital cost. According to the Porter, If any of these factors are powerful, the firm's capability of increasing the prices and profitability decreases. Because the complication of the competition factors will be a threat for the firm. On the other hand, a weak competition factor provides the firm more profit opportunity (Şimşek \& Akın, 2003: 93). In Figure 2., Porter's five competition forces are indicated.

\section{Figure 2. Porter's Five Forces.}

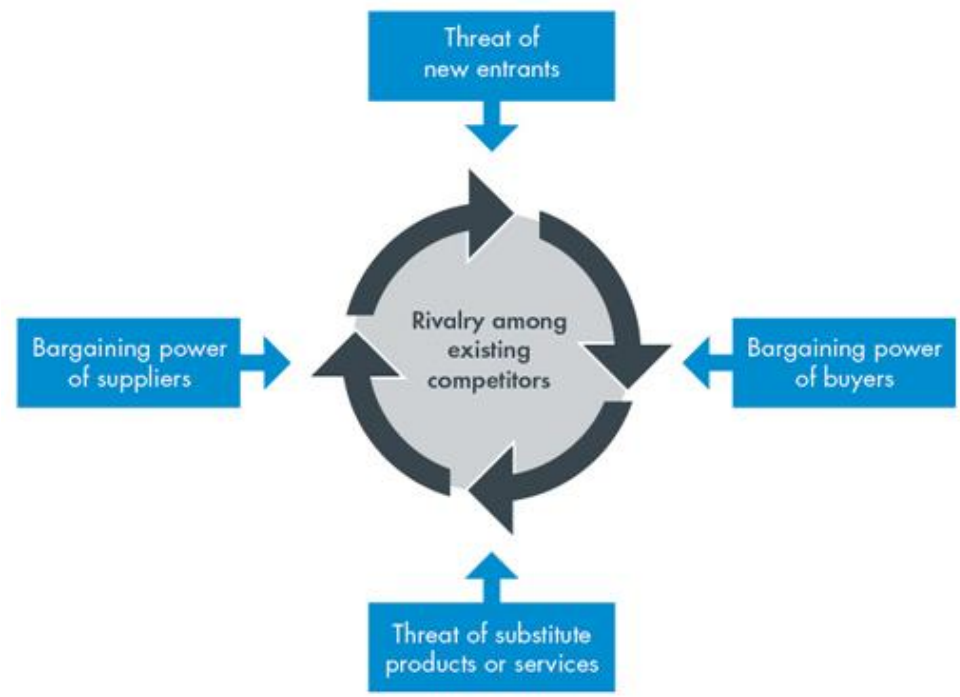

\subsection{The Relationship Between R\&D and Supply Chain.}

If there is an effective relationship between R\&D and Supply Chain Management (SCM), any factor which can affect the competitive advantage gained by the products of the firm, which are in the supply chain, should be eliminated via R\&D. Any problem which can make competitive disadvantage caused by the suppliers should be solved and even can be transformed to the competitive advantage. Therefore, the relationship between the managers of R\&D and The Supply Chain Managers should be very strong, mutual processes should be informed them by each other and the structure of the organization should be shaped in this context. Afterwards, quickly projected R\&D processes should be started so that any possible lose of competency should be prevented.

Technoparks are the fields that firms can have chance to take part in R\&D processes. University-Industry Collaboration Model, which combines new information and technological application under the same roof, is worldwide model with proven affects in the technology-based development of the countries.

Etzkowitz's "Triple Helix Model" that deals with the theoretical structure of university-industry-government cooperation, covers the University for generating knowledge through research, the Industry for transferring this knowledge into practice, the state for providing the necessary support for the formation of fruitful collaboration platform. Technoparks brings together this trio collaboration under the same roof. According to The United Kingdom Science Park Association (UKSPA), a technopark is an initiative which establishes official relations with a university or a higher education institution or a research center, designed to encourage technology based companies to start and grow within, providing technology and business skill transfers to the relevant companies effectively. Teknoparks can also be an alternative for the cooperation of SCM and R\&D.

\section{Conclusion}

In this paper, I tried to show the reflections of supply chain practices on R\&D. In our era of globalization, realizing the importance of supply chain management and R\&D on competitive advantage is inevitable. They are both very critical on 
the process of production. As we can understand from the literature review, supply chains affect both inbound and outbound logistics, which is the significant part of production and sales. Similarly, the criticality of the R\&D unit can be understood from the literature review also. It is clear that remaining its position for a firm in the area of competition is relevant to the new products, cheaper substitute products or services and these are directly related to process of R\&D.

Taking into consideration Porter's five forces, managers have to analyze the opportunities and threats particularly for not to lose competitive advantage or keep it. Main purpose of the competition strategy should be orientating to the rules of competition and changing this rules in favor of the firm. So that when we examine them with the five forces; threat of new entrants, rivalry among existing competitors, bargaining power of buyers, bargaining power of suppliers, threat of the substitute products or services can be seen as a mutual concern of both R\&D and Supply Chain Managers. So that, the cooperation between them should be provided. Mutual processes should be informed them by each other and the structure of the organization should be shaped in this context. Afterwards, quickly projected R\&D processes should be started so that any possible lose of competency should be prevented.

In this paper, I tried to show the strong relationship between R\&D and SCM with a literature review because there is not so many studies or researches about this relationship. But a qualitative or quantitative research can be made examining to understand that:

How should structure of organizations be,

How should the sharing of responsibility between them be,

What kinds of problems can be solved with their coordination,

What the possible effect of their successful coordination to the competitive advantage is

\section{References}

[1] AKIN,H.B.(2005).Yeni Ekonomi,Konya: Çizgi Kitapevi Balaban,Y.(2005, 1 Şubat). Ar-Ge Ligi'nin Şampiyonları,Kapital Dergisi

[2] AKGÜN, M., (2004), "Tedarik Zinciri Yönetiminde Bütünleşik Faaliyet-Tabanlı-Hedef Maliyetleme Yaklaşımı”, MODAV Muhasebe Bilim Dünyası Dergisi, Cilt:6, Sayı:1, Mart.

[3] AKTAŞ, İ., (2005), "Muhasebe ve Finansman Alanında Dış Kaynak Kullanımı" , T.C. İstanbul Ticaret Üniversitesi, Sosyal Bilimler Enstitüsü, Muhasebe ve Denetim Yüksek Lisans Programı, Yayınlanmamış Yüksek Lisans Bitirme Projesi, İstanbul: Temmuz.

[4] AYDEMIR, İ., (2005), "Maliyet Yönetimi Konusundaki Yeni Yaklaşımlar ve Muhasebe Eğitimi ve Uygulamalarına Yansıması", XXIV. Türkiye Muhasebe Eğitimi Sempozyumu Muhasebe Ortamındaki Güncel Gelişmeler ve Muhasebe Eğitimine Etkileri, 27-30 Nisan.

[5] AYSAN, M., (1974), "Maliyetler ve İşletme Kararları", Fakülteler Matbaası, İstanbul.

[6] BARUTÇUGiL, S. (1988). Üretim Sistemleri ve Yönetimi Teknikleri. Bursa: Uludağ Üniversitesi Yayınları.

[7] BLANCHARD D. (2010), Supply Chain Management Best Practices, 2nd. Edition, John Wiley \& Sons, ISBN 9780470531884

[8] BOWERSOX, Donald J, (1978), Logistical Management-A Systems Integration of Physical Distribution and Materials Management, New York: Macmillan Publishing Co., Inc.

[9] BULDURGAN, M.(2008), Faaliyet Raporu CEO Mesajı, Temsa Global A.Ş.

[10] CAN, V., (2004), "Maliyet Yönetimi Aracı Olarak 'OUTSOURCING' (Bir Nakliye Şirketi Örneği)", MÖDAV Muhasebe Bilim Dünyası Dergisi, Cilt:6, Sayı:3, Eylül.

[11] CAVINATO, J. L., KAUfMANN, R. G., (2000), "The Purchasing Handbook: A Guide for the Purchasing Ans Supply Professional", 6.Baskı, Mc Graw- Hill, New York. 
[12] CERAN, Y., (2003), "Hedef Maliyetleme Yöntemini Destekleyici Bir Enstrüman Olarak Ürün Geliştirme ve Tasarım Anında Maliyet Hesaplama", MÖDAV Muhasebe Bilim Dünyası Dergisi, Cilt:5, Sayı:4, Aralık.

[13] CHOPRA, S., MEINDL, P., (2004), "Supply Chain Management: Strategy, Planning and Operation”, 2. Baskı, Prentice Hall.

[14] ÇEVIK, F.(2002). İhracata Yönelik Devlet Yardımlarının Karaman Gıda Sektörü Üzerinde Bir Değerlendirmesi, Karaman I.I.B.F

[15] DEVREZ, G. (1970 ). İşletmelerde Araştırma ve Geliştirme Fonksiyonu.Ankara: Ankara Üniversitesi Siyasal Bilimler Fakültesi , s. 236.

[16] DURSUN, A., (2001), "Tam Zamanında Üretim (TZÜ) Sisteminde Standart Maliyet Fark Analizleri", Muhasebe ve Denetim Bakış, Yıl: 1, Sayı:2, Ocak.

[17] ERDEN, A., (2003), "Maliyet Yönetimi ve Küresel Rekabete Yönelik Maliyetleme", MÖDAV Muhasebe Bilim Dünyası Dergisi, Cilt:5, Sayı:4, Aralık.

[18] ERTÜRK, M.(2000). İşletme Biliminin Temel İlkeleri, İstanbul: Beta Basım Yayın Dağıtım A.Ş. 4. Baskı,s.56

[19] FEARON, Leenders, Johnson, Flynn (2002), Purchasing and Supply Management, NewYork: McGraw-Hill

[20] FELLER A., SHUNK D., \& CALLARMAN T. (2006). BPTrends, March 2006 - Value Chains Vs. Supply Chains

[21] FRAZELLE, E. (2002): Supply Chain Strategy: The Logistics of Supply Chain Management, New York : McGraw-Hill

[22] FRASCATI KILAVUZU (2002), Araştırma ve Deneysel Geliştirme Taramaları için Önerilen Standart Uygulama, OECD (Ekonomik İşbirliği ve Kalkınma Örgütü)

[23] GÜLEŞ, H. K., \& BÜLBÜL, H. (2004). Yenilikçilik. Ankara: Nobel Yayınları.

[24] HINES, T. 2004. Supply chain strategies: Customer driven and customer focused. Oxford: Elsevier.

[25] ILTER, H. M., (2002), "Global Dışsal Tedarik (Outsourcing)", İstanbul Ticaret Odası Yayınları, Yayın No: 2002-31, İstanbul.

[26] JACOBY, D.(2009), Guide to Supply Chain Management: How Getting it Right Boosts Corporate Performance (The Economist Books), Bloomberg Press; 1st edition, ISBN 978-1576603451

[27] KÖSE, T., (2005), "Maliyet Yönetiminde Faaliyet Analizi ve Bir Uygulama", MÖDAV Muhasebe Bilim Dünyası Dergisi, Cilt:7, Sayı:1, Mart.

[28] KAHYAOĞLU Aytaç, G. (2009).Bisküvi ,T.C. Başbakanlık Dış Ticaret Müsteşarlığı Ihracatı Geliştirme Etüd Merkezi

[29] KASILINGAM, R.G. (1999): Logistics and Transportation: Design and Planning, first ed., Springer, London.

[30] KAYKAYOĞLU, R. (2008). Ar-Ge'de dünya 25'incisiyiz, PC TIME

[31] KAYMAKÇALAN, Ö. (1997).Teknoloji Geliştirme ve Transfer Aracı Olarak Teknoparklar,Dünyada ve Türkiyen Örnekler ,ístanbul:Teknoloji Yönetim Derneği Bildiriler Kitabı

[32] KURTALAN, M. (2009), "Küresel Rekabet Ortamında İşletmelerde Teknoloji Geliştirme Birimlerinin Kurulması ve Teknoloji Yönetimi”, Yüksek Lisans Tezi, Karamanoğlu Mehmet Bey Üniversitesi, Karaman.

[33] LYSONS, K., (2000), "Purchasing and Supply Chain Management", Addison Wesley, 5.Basım, England.

[34] MENTZER, J.T.; et al. (2001). "Defining Supply Chain Management". Journal of Business Logistics. 22 (2):

[35] ÖKER, F., (2003), "Faaliyet Tabanlı Maliyetleme Üretim ve Hizmet İşletmelerinde Uygulamalar", Literatür Yayınları: 109, Birinci Basım, Kasım.

[36] ÖNER, M. (2006). Ar-Ge Yönetimi. İstanbul: Boğaziçi Üniversitesi Yayınevi.s.5 
[37] ÖZBAY, T., (2004), "Sorularla Dış Kaynak Kullanımı (Outsourcing)", İstanbul Ticaret Odası Yayınları, Yayın No:200427, İstanbul.

[38] ÖZKAN, A., AKSOYLU, S., (2002), "Kaizen ve Faaliyete Dayalı Maliyetlemenin Birlikte Uygulanabilirliği", MÖDAV Muhasebe Bilim Dünyası Dergisi, Cilt:4, Sayı:3, Eylül.

[39] PEKDEMIR, R., (1998), "Faaliyet Tabanlı Maliyetleme ve Genel İmalat Maliyetleri", Temel Eğitim ve Staj Merkezi, Yayın No: 17, ìstanbul.

[40] PORTER, Michael E.(2000): Rekabet Stratejisi Sektör ve Rakip Analizi Teknikleri, İstanbul, Sistem Yayınclık, 2000.

[41] REKABET FORUMU - IMD, Yabancı Teknoloji Firmalarının Çin'deki Ar-Ge Yatıımlarına Yaklaşımı, Teknoloji, 28.09.2007, http://www.ref.sabanciuniv.edu/

[42] SABIR, H. (2007). Küreselleşen Pazar Ekonomileri ve Rekabet Politikaları. İstanbul: Derin Yayınları.

[43] SARIHAN, F. (1998). Teknoloji Yönetimi. İstanbul: Alcatel Yayınları

[44] SERASLAN, N., (2002), "Türkiye Uygulamaları: Lojistik ve Tedarik Yönetimi”, Orhim Organizasyon ve Halkla Illişkiler Merkezi Limited Şirketi, 10-12 Haziran Eğitim Notları.

[45] ŞiMŞEK, M., \& AKIN, H. (2003). Teknoloji Yönetimi ve Örgütsel Değişim. Konya: Çizgi Yayınları.

[46] ŞAKRAK, M., (1997), "Maliyet Yönetimi: Maliyet ve Yönetim Muhasebesinde Yeni Yaklaşımlar", Yasa Yayınları, İstanbul.

[47] ŞEN, E. , (2004), "Kobi'lerin Uluslararası Rekabet Güçlerini Arttırmada Tedarik Zinciri Yönetiminin Önemi”, İhracatı Geliştirme Etüd Merkezi, Aralık.

[48] TAMER, M. (1997), "Eczacıbaşı hem Koç.hemde Sabancı gibi", Ekonomi Kulusi, 11 Ocak 1997, Milliyet Gazetesi

[49] TEKER, E. Sanayileşme Sürecinde Teknoloji Üretimi, Transferi ve Uygun Teknoloji Seçimi, Mühendisler Mimarlar Odası (arsiv.mmo.org.tr/pdf/10630.pdf),s.185)

[50] TOSUN, K., (1971), "İ̧sletme Yönetimi”, Fakülteler Matbaası, İstanbul.

[51] TUNCER, Y. (1974). Ekonomik Açıdan Bilime Dayalı Teknoloji Üretimi . O.D.T.Ü. Geliştirme Dergisi , s.74-75.

[52] TÜRK, M. (2003). Küreselleşme Sürecinde İşletmelerde Bilgi Yönetimi, İstanbul: Türkmen Yayınları, s.5

[53] TÜRKER, M., BALYEMEZ, F., BiÇER, A., (2005) “Üretim Sürecinde Tedarik Zincirinin Önemi ve Maliyet Yönetimi” V. Ulusal Üretim Araştırmaları Sempozyumu, İstanbul Ticaret Üniversitesi, 25-27 Kasım 2005

[54] ÜRETEN, S. (1999). Stratejik Kararlar ve Karar Modelleri, Üretim/iş̧lemler Yönetimi (s. 248-249). Ankara: Başar Ofset.

[55] ÜSTEL, I.\&KABATEPE, E.(2006), Kobiler ve İnovasyon, AB - Türkiye İşbirliği Derneği,s:16

[56] YETiŞ, N. (1993).Teknoloji geliştirme ve Risk Sermayesi, Risk Sermaye Paneli. İstanbul: İstanbul Sanayi Odası.

[57] YÜKÇÜ, S., ÖZKAN, S., (2003), "Teknolojik Gelişmelerin Maliyet Muhasebesine Etkileri”, XXII. Türkiye Muhasebe Eğitimi Sempozyumu Muhasebe-Eğitim: Eğilim ve Etkileşimler, 21-25 Mayıs.

[58] ZERENLER, M. \& TÜRKER, N. \& Şahin,E. (2007), Küresel Teknoloji, Araştırma-Geliştirme (AR-GE) ve Yenilik Ilişkisi Selçuk Üniversitesi Sosyal Bilimler Enstitüsü Dergisi, Sayı 17, s. 657

[59] https://en.wikipedia.org/wiki/Research and development

[60] http://www.investopedia.com/terms/r/randd.asp 